\title{
XANTHINE OXIDASE INHIBITORY PROPERTIES OF 1,2,3,4-TETRAHYDROISOQUINOLINE DERIVATIVES
}

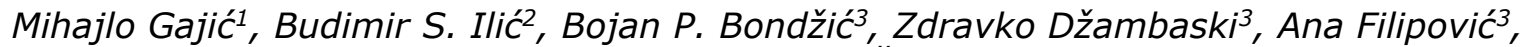 \\ Gordana Kocićt ${ }^{4}$ Andrija Šmelcerović 2
}

\begin{abstract}
Xanthine oxidase $(\mathrm{XO})$ is a versatile metalloflavoprotein enzyme that is best known for its rate-limiting role in the purine degradation pathway. Therapeutic inhibition of $X O$ is based on its role in a variety of diseases that is attributed either to the hyperproduction of uric acid, or the hyperproduction of reactive oxygen species. Herein, we report the assessment of XO inhibitory properties of 24 1,2,3,4-tetrahydroisoquinoline derivatives, among which compound 16 exhibited $\mathrm{IC}_{50}$ value of $135.72 \pm 2.71 \mu \mathrm{M}$. The interaction of compound 16 with XO enzyme was simulated using the Site Finder module, molecular docking and molecular dynamics. Molecular modeling suggests that interactions with Met 1038, Gln 1040, Thr 1077, Gln 1194 and Val 1259 are an important factor for inhibitor affinity toward the XO enzyme. Our proposed binding model might be beneficial for the discovery of new active 1,2,3,4-tetrahydroisoquinoline-based inhibitors of XO enzyme.
\end{abstract}

Acta Medica Medianae 2021;60(1):48-55.

Key words: xanthine oxidase inhibition, 1,2,3,4-tetrahydroisoquinolines, molecular docking, molecular dynamic simulation

\footnotetext{
${ }^{1}$ University of Niš, Faculty of Medicine, Department of Pharmacy, Niš, Serbia

${ }^{2}$ University of Niš, Faculty of Medicine, Department of Chemistry, Niš, Serbia

3University of Belgrade, Institute of Chemistry, Technology and Metallurgy, Belgrade, Serbia

${ }^{4}$ University of Niš, Faculty of Medicine, Department of Biochemistry, Niš, Serbia
}

Contact: Andrija Šmelcerović

48 Dr Zoran Djindjić Blvd., 18000 Niš, Serbia

E-mail: andrija.smelcerovic@medfak.ni.ac.rs a.smelcerovic@yahoo.com while conversion to XO occurs in pathological conditions, after XDH proteolysis or oxidation of some of its sulfhydryl residues (1). Superoxide anion radical and hydrogen peroxide that are generated as the byproducts of enzyme activity are responsible for oxidative stress which usually accompanies elevated XO activity. The role of XO in diseases is attributed either to the hyperproduction of uric acid, or the hyperproduction of reactive oxygen species. Therefore, pharmacological inhibition of xanthine oxidase is proven to be invaluable for the treatment of hyperuricemia and gout in the first place, but might also be beneficial for plethora of conditions, such as cholecystitis, hemorrhagic shock, ischemia-reperfusion injuries, hypercholesterolemia and carcinogenesis (4).

Given the broad therapeutic potential of XO inhibitors, the aim of the current study was to assess a group of 24 1,2,3,4-tetrahydroisoquinoline derivatives for potential inhibitory properties against $\mathrm{XO}$ and to perform molecular docking and molecular dynamics simulation on active compounds, in order to elucidate key structural features responsible for XO inhibitory activity.

\section{Materials and methods}

\section{Compounds}

The synthesis of 24 1,2,3,4-tetrahydroisoquinoline derivatives was preformed according to the description in our previous study (5). ubsequently producing uric acid $(2,3)$. drogenase form is predominant in healthy tissues, 48 


\section{Evaluation of xanthine oxidase inhibition}

Compounds were studied for inhibitory properties against bovine milk xanthine oxidase. Spectrophotometric measurement of uric acid formation at $293 \mathrm{~nm}$ was used for in vitro evaluation of enzyme inhibition, as described in our previous studies $(6,7)$. Initially, all compounds were assayed at a concentration of $150 \mu \mathrm{M}$, while those inhibiting more than $50 \%$ of enzyme activity were subsequently tested in a broader concentration range to allow for $\mathrm{IC}_{50}$ determination. Allopurinol was used as a positive control. All experiments were performed in triplicate and averaged.

\section{Ligand preparation}

Examined inhibitor was generated using the builder panel in the Molecular Operating Environment (MOE) 2019.0101 software (8). Using the MOE LigX module, partial atomic charges were ascribed and possible ionization states were generated at a $\mathrm{pH}$ of 7.0. The MMFF94x force field was used for optimization and the resulting structure was used for modeling studies. Conformational search was carried out by MOE LowModelMD method which performs molecular dynamic perturbations along with low frequency vibrational modes with energy window of $7 \mathrm{kcal} / \mathrm{mol}$, and conformational limits of 1000 .

\section{Receptor preparation}

The X-ray crystallographic structure of $\mathrm{XO}$ enzyme (PDB code: 1 N5X), retrieved from the Protein Data Bank, was prepared using the Structure Preparation process in MOE. After the correction, hydrogens were added and partial charges (Gasteiger methodology) were calculated. Energy minimization (AMBER14:EHT, RMS gradient: 0.100) was performed.

\section{Binding site selection}

The Site Finder module of the MOE was used to identify possible ligand-binding sites within the optimized structure of XO enzyme. Hydrophobic or hydrophilic alpha spheres served as probes denoting zones of tight atom packing. These alpha spheres were utilized to define and rank potential ligandbinding sites according to their propensity for ligand binding (PLB) score, which was based on the amino acid composition of the pocket (9).

\section{Docking protocol}

The molecular docking study was performed using the MOE to understand the ligand/protein interactions in detail. The default Triangle Matcher placement method was used for the induced fit docking. GBVI/WSA dG scoring function which estimates the free energy of binding of the ligand from a given pose was used to rank the final poses. The ligand/protein complex with lowest relative binding free energy $(\Delta G)$ score was selected for further study.

\section{Molecular dynamics simulation}

The molecular dynamics simulation of compound 16 on XO enzyme, was carried out using the Desmond Molecular Dynamics System (Desmond) 2018.4 software (10). The structure of the added water was based on the simple point charge (SPC) solvent model. The system was neutralized with $\mathrm{Na}^{+}$ ions to balance the net charge of the whole simulation box to neutral. The final system contained approximately 123,000 atoms. The system was passed through a 6-step relaxation protocol before molecular dynamics simulations. The relaxed system was simulated for $10 \mathrm{~ns}$, using a normal pressure temperature (NPT) ensemble with a Nosé-Hoover thermostat at $300 \mathrm{~K}$ and Martyna-Tobias-Klein barostat at 1.01325 bar pressure. Atomic coordinate data and system energies were recorded every 1 ps. The root mean square deviation (RMSD) and root mean square fluctuation (RMSF) of the inhibitor/XO enzyme complex were analyzed with respect to the simulation time.

\section{Results and discussion}

Previously synthetized 1,2,3,4-tetrahydroisoquinoline derivatives (5) were assayed for potential in vitro XO inhibitory properties. Among 24 tested compounds (Table 1 ), IC 50 value below $150 \mu \mathrm{M}$ was observed only in the case of $16(135.72 \pm 2.71 \mu \mathrm{M})$. Analysis of structural features of active compound 16 and its closest inactive analog 17 indicate to 7,8dimethoxy substitution on 1,2,3,4-tetrahydroisoquinoline core as a probable cause for the lack of $\mathrm{XO}$ inhibitory properties of 17 . Identified active compound 2-(4-fluorophenyl)-1,2,3,4-tetrahydroisoquinoline-1-carbonitrile (16) was subjected to docking studies and molecular dynamics simulation with the goal to provide insight into the key structural features required for its XO inhibitory activity.

By combining a novel and highly effective algorithm for rapid binding-site evaluation with easy-to-use property visualization tools, Site Finder provides researchers with efficient means to identify and characterize binding sites (9). The results from the Site Finder analysis highlighted that catalytic residues like Gln 767, Glu 802, Arg 880, Phe 914, Phe 1009 and Glu $1261(11,12)$ constituted the topranked binding pocket of XO enzyme (Table 2, Figure 1).

The intermolecular contacts between examined inhibitor and XO enzyme were analyzed using the ligand interaction diagram of MOE suite (Table 3, Figure 2). It illustrates the existence of hydrogen bond and $\mathrm{pi}-\mathrm{H}$ interactions. Additionally, the bond distances, bond energy and binding free energy between the inhibitor and receptor atoms were also examined (Table 3 ). The molecular docking highlighted the importance of Met 1038, Gln 1040, Thr 1077, Gln 1194 and Val 1259 in the formation of inhibitor/XO enzyme complex (Table 3, Figure 2). Observed interactions between 16 and non-catalytic 
residues (Table 3 , Figure 2 ), are similar to molecular interplay involving non-purine XO inhibitors (13-16). Some of recently synthesized pyrazole derivatives were found to inhibit XO enzyme via Met 1038, Gln 1040 and Gln 1194 residues (13). Furthermore, inhibitory effect of verbascoside on XO activity, can be attributed to the formation of hydrogen bond with Gln 1194 residue (14). Moreover, molecular simulation revealed that newly synthesized hesperidin derivatives interacted with $\mathrm{XO}$ residues Met 1038, Gln 1040, Thr 1077, Gln 1194 and Val 1259 (15). Additionally, molecular docking revealed that 1,4-dicaffeoylquinic acid interacted with XO enzyme via Gln 1040 and Thr 1077 residues (16).

Table 1. In vitro XO inhibitory activity of 1,2,3,4-tetrahydroisoquinolines

\begin{tabular}{|c|c|c|c|c|c|}
\hline Compd. & 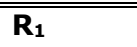 & $\overline{\mathbf{R}_{2}}$ & $\overline{\mathbf{R}_{\mathbf{3}}}$ & 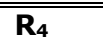 & 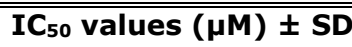 \\
\hline 1 & $\mathrm{H}$ & $\mathrm{CH}_{2} \mathrm{COCH}_{3}$ & $\mathrm{H}$ & $\mathrm{H}$ & $>150$ \\
\hline 2 & $\mathrm{H}$ & $\mathrm{CH}_{2} \mathrm{COCH}_{3}$ & $\mathrm{OCH}_{3}$ & $\mathrm{OCH}_{3}$ & $>150$ \\
\hline 3 & $\mathrm{Ph}$ & $\mathrm{CH}_{2} \mathrm{COCH}_{3}$ & $\mathrm{H}$ & $\mathrm{H}$ & $>150$ \\
\hline 4 & $\mathrm{Ph}$ & $\mathrm{CH}_{2} \mathrm{COCH}_{3}$ & $\mathrm{OCH}_{3}$ & $\mathrm{OCH}_{3}$ & $>150$ \\
\hline 5 & $\mathrm{Ph}$ & $\mathrm{CH}_{2} \mathrm{COCH}_{2} \mathrm{CH}_{3}$ & $\mathrm{H}$ & $\mathrm{H}$ & $>150$ \\
\hline 6 & $\mathrm{Ph}$ & $\mathrm{CH}_{2} \mathrm{COCH}_{2} \mathrm{CH}_{3}$ & $\mathrm{OCH}_{3}$ & $\mathrm{OCH}_{3}$ & $>150$ \\
\hline 7 & $\mathrm{Ph}$ & $\mathrm{CH}_{2} \mathrm{COPh}$ & $\mathrm{H}$ & $\mathrm{H}$ & $>150$ \\
\hline 8 & $\mathrm{Ph}$ & $\mathrm{CH}_{2} \mathrm{COPh}$ & $\mathrm{OCH}_{3}$ & $\mathrm{OCH}_{3}$ & $>150$ \\
\hline 9 & $\mathrm{Ph}$ & 2-oxocyclohexane & $\mathrm{H}$ & $\mathrm{H}$ & $>150$ \\
\hline 10 & o-Me-Ph & $\mathrm{CH}_{2} \mathrm{COCH}_{3}$ & $\mathrm{H}$ & $\mathrm{H}$ & $>150$ \\
\hline 11 & $p-\mathrm{F}-\mathrm{Ph}$ & $\mathrm{CH}_{2} \mathrm{COCH}_{3}$ & $\mathrm{H}$ & $\mathrm{H}$ & $>150$ \\
\hline 12 & $p-\mathrm{F}-\mathrm{Ph}$ & $\mathrm{CH}_{2} \mathrm{COCH}_{3}$ & $\mathrm{OCH}_{3}$ & $\mathrm{OCH}_{3}$ & $>150$ \\
\hline 13 & $p-\mathrm{F}-\mathrm{Ph}$ & $\mathrm{CH}_{2} \mathrm{COCH}_{2} \mathrm{CH}_{3}$ & $\mathrm{H}$ & $\mathrm{H}$ & $>150$ \\
\hline 14 & $p-\mathrm{F}-\mathrm{Ph}$ & $\mathrm{CH}_{2} \mathrm{COCH}_{2} \mathrm{CH}_{3}$ & $\mathrm{OCH}_{3}$ & $\mathrm{OCH}_{3}$ & $>150$ \\
\hline 15 & $p-\mathrm{F}-\mathrm{Ph}$ & $\mathrm{CH}_{2} \mathrm{COPh}$ & $\mathrm{H}$ & $\mathrm{H}$ & $>150$ \\
\hline 16 & $p-\mathrm{F}-\mathrm{Ph}$ & $\mathrm{CN}$ & $\mathrm{H}$ & $\mathrm{H}$ & $135.72 \pm 2.71$ \\
\hline 17 & $p-\mathrm{F}-\mathrm{Ph}$ & $\mathrm{CN}$ & $\mathrm{OCH}_{3}$ & $\mathrm{OCH}_{3}$ & $>150$ \\
\hline 18 & $p-\mathrm{F}-\mathrm{Ph}$ & 2-oxocyclohexane & $\mathrm{H}$ & $\mathrm{H}$ & $>150$ \\
\hline 19 & $p-\mathrm{F}-\mathrm{Ph}$ & 2-oxocyclohexane & $\mathrm{OCH}_{3}$ & $\mathrm{OCH}_{3}$ & $>150$ \\
\hline 20 & $p$-Me-Ph & $\mathrm{CH}_{2} \mathrm{COCH}_{3}$ & $\mathrm{H}$ & $\mathrm{H}$ & $>150$ \\
\hline 21 & $p$-Me-Ph & $\mathrm{CH}_{2} \mathrm{COPh}$ & $\mathrm{H}$ & $\mathrm{H}$ & $>150$ \\
\hline 22 & $p$-Me-Ph & $\mathrm{CH}_{2} \mathrm{COPh}$ & $\mathrm{OCH}_{3}$ & $\mathrm{OCH}_{3}$ & $>150$ \\
\hline 23 & $p$-Me-Ph & $\mathrm{CH}_{2} \mathrm{COCH}_{2} \mathrm{CH}_{3}$ & $\mathrm{OCH}_{3}$ & $\mathrm{OCH}_{3}$ & $>150$ \\
\hline 24 & $p$-Me-Ph & $\mathrm{CN}$ & $\mathrm{OCH}_{3}$ & $\mathrm{OCH}_{3}$ & $>150$ \\
\hline
\end{tabular}


Table 2. Summary of the top five inhibitor-binding sites in XO

\begin{tabular}{|c|c|c|c|c|c|}
\hline Site & Size & PLB & Hyd & Side & Residues \\
\hline 1 & 172 & 1.31 & 49 & 95 & 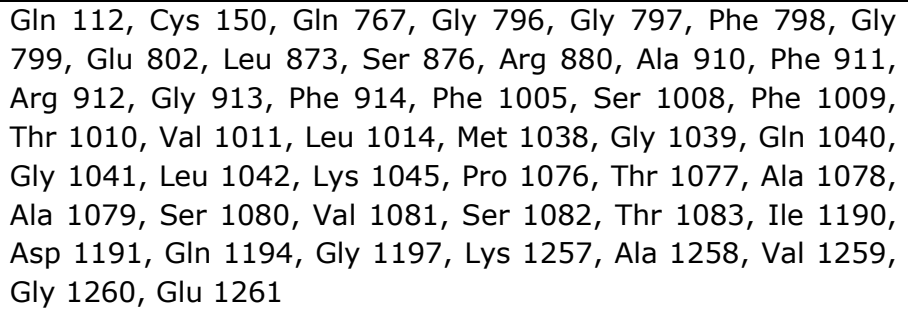 \\
\hline 2 & 98 & 0.87 & 35 & 63 & $\begin{array}{l}\text { Cys 662, Val 663, Ile 696, Thr 697, Ile 698, Glu 699, Tyr 735, } \\
\text { Gly 738, Gln 739, Asp 740, His 741, Asp 832, Met 833, Leu } \\
\text { 834, Ile 835, Thr 836, Gly 837, Gly 838, Arg 839, Pro 841, Asn } \\
866 \text {, Asn 904, Leu 905, Ser 906, Asn 908, Leu 1211, Tyr } \\
\text { 1213, Ser } 1214 \text {, Pro 1215, Gly } 1217 \text {, Ser } 1218 \text {, Leu 1219, Thr } \\
1221 \text {, Arg } 1222\end{array}$ \\
\hline 3 & 101 & 0.68 & 20 & 60 & $\begin{array}{l}\text { His 614, Asp 651, Glu 652, Thr 653, Thr 661, Cys 662, Val } \\
\text { 663, Gly 664, His 665, Ile 666, Pro 693, Ala 694, Ile 695, Ser } \\
\text { 706, Tyr 708, Arg 804, Leu 807, Leu 834, Ile 835, Thr 836, } \\
\text { Gly 837, Gly 868, Asn 869, Ser 870, Arg 871, Lys 902, Thr } \\
\text { 903, Asn 904, Ser 906, Ser } 907\end{array}$ \\
\hline 4 & 185 & 0.59 & 51 & 95 & $\begin{array}{l}\text { Gln 62, Ile 66, His 67, Phe 68, Ser 69, Ser 123, Thr 126, Leu } \\
\text { 127, Asn 130, Gln 131, Glu 137, Glu 138, Asp 141, Ala 142, } \\
\text { Gln 144, Ala 304, Ser 306, Ser 307, Glu 309, Lys 310, Leu } \\
\text { 313, Arg 328, Leu 331, Glu 332, Leu 334, Arg 335, Trp 336, } \\
\text { Lys 340, Gln 341, Lys 343, Ser 344, Leu 548, Gln 550, Lys } \\
551\end{array}$ \\
\hline 5 & 95 & 0.54 & 34 & 63 & $\begin{array}{l}\text { Leu 952, Asn 956, Gln 957, Arg 958, Leu 959, Glu 960, Gly } \\
\text { 961, Ser 963, Pro 1136, Asn 1137, Leu 1138, Asn 1148, Phe } \\
\text { 1150, His 1151, Tyr 1152, Phe 1153, Tyr 1155, Asp 1181, Gly } \\
1183 \text {, Cys 1247, Pro 1248, Asn 1249, Lys 1250, Lys 1251, Lys } \\
1257\end{array}$ \\
\hline
\end{tabular}

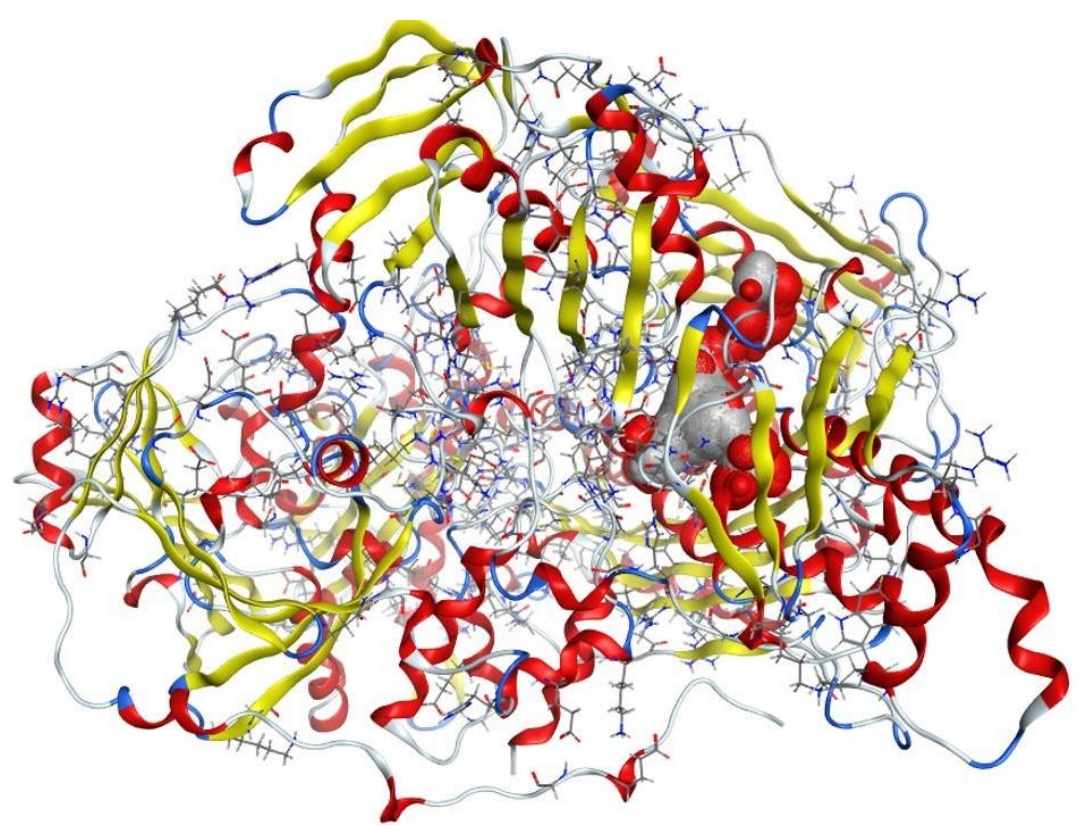

Figure 1. The top ranked XO binding site, represented by a grey-red surface map 
Table 3. Summary of the 16 interactions with protein residues in $\mathrm{XO}$

\begin{tabular}{|c|c|c|c|c|c|c|}
\hline Inhibitor & $\begin{array}{l}\text { Inhibitor } \\
\text { atoms }\end{array}$ & $\begin{array}{l}\text { Protein } \\
\text { residue }\end{array}$ & $\begin{array}{c}\text { Inhibitor-Protein } \\
\text { Interactions }\end{array}$ & $\begin{array}{l}\text { Distance } \\
(\AA)\end{array}$ & $\begin{array}{c}E \\
(\mathrm{kcal} / \mathrm{mol})\end{array}$ & $\begin{array}{l}\Delta \text { G binding } \\
\text { (kcal/mol) }\end{array}$ \\
\hline \multirow{5}{*}{16} & $\mathrm{C} 10$ & Met 1038 & H-donor & 4.29 & -0.3 & \multirow{5}{*}{-8.36} \\
\hline & $\mathrm{C} 12$ & Gln 1194 & H-donor & 3.06 & -0.5 & \\
\hline & N19 & Thr 1077 & $\mathrm{H}$-acceptor & 3.47 & 2.2 & \\
\hline & 6-ring & Gln 1040 & $\mathrm{pi}-\mathrm{H}$ & 4.41 & -0.2 & \\
\hline & 6-ring & Val 1259 & $\mathrm{pi}-\mathrm{H}$ & 4.64 & -0.4 & \\
\hline
\end{tabular}

A

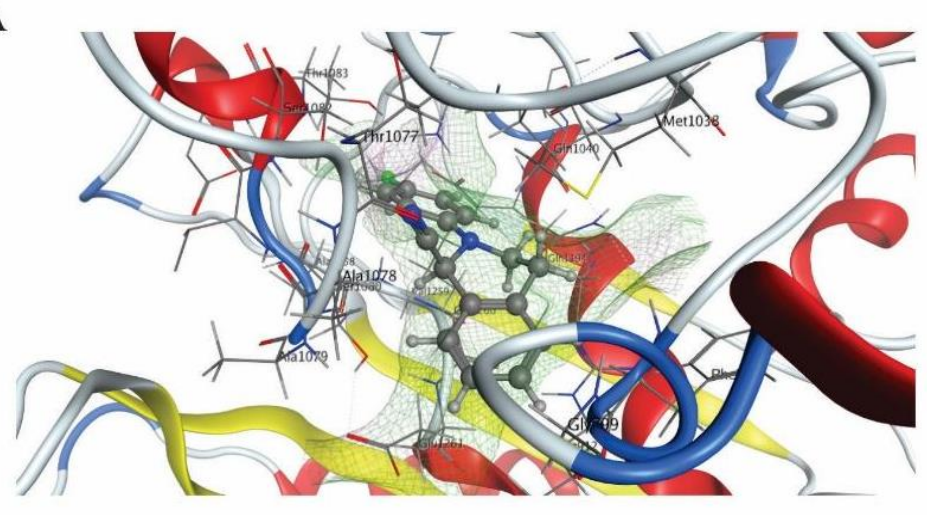

B

Gly

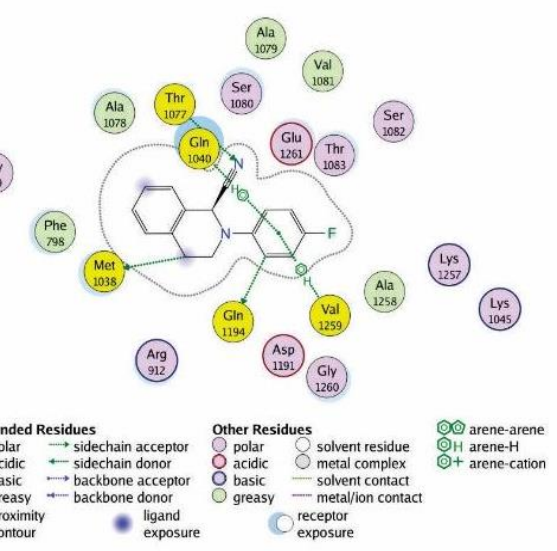

Figure 2. 3D/2D view of compound $16(A, B)$ bound in the active site of $X O$.

The polar part of the active site is shown as a pink surface, hydrophobic part as a green surface, while the solvent exposed part is shown as a red surface.

The study was further extended to assess the stability of $16 / \mathrm{XO}$ enzyme complex through the molecular dynamics simulation. The RMSD and RMSF plots for XO enzyme and examined inhibitor showed that docking complex was stable during entire simulation period (Figures 3-4). The RMSD for $\mathrm{Ca}$, side chains and heavy atoms remained within the limit of $2 \AA$. The similar situation was noted for RMSF values. The obtained results indicated small structural rearrangements, less conformational changes and confirmed stability of $16 / \mathrm{XO}$ enzyme complex (17).
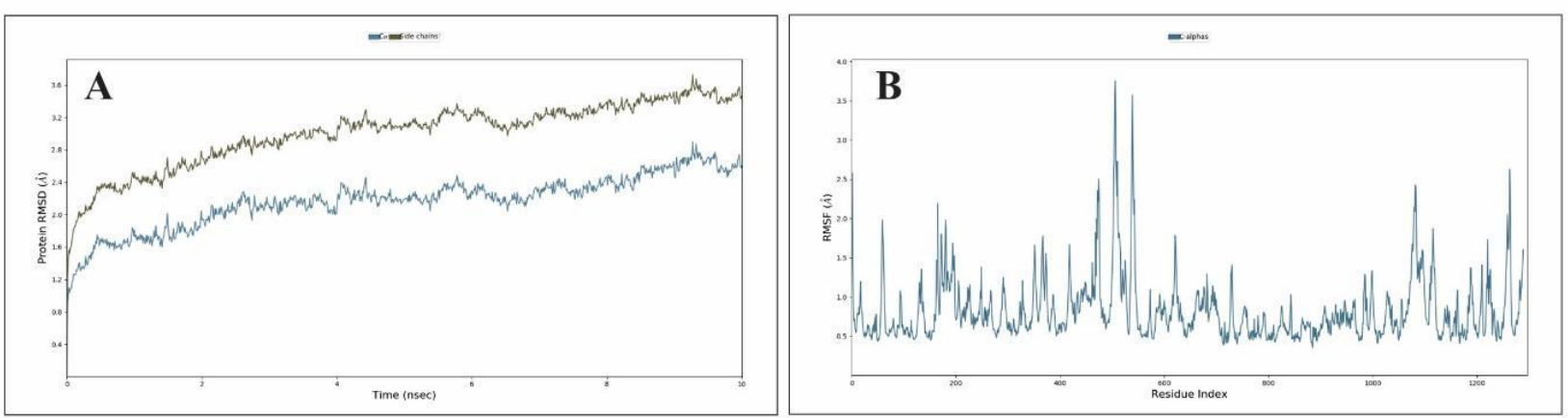

Figure 3. RMSD (A) and RMSF (B) plot of $\mathrm{XO}$, obtained during the course of 10 ns molecular dynamics simulation 

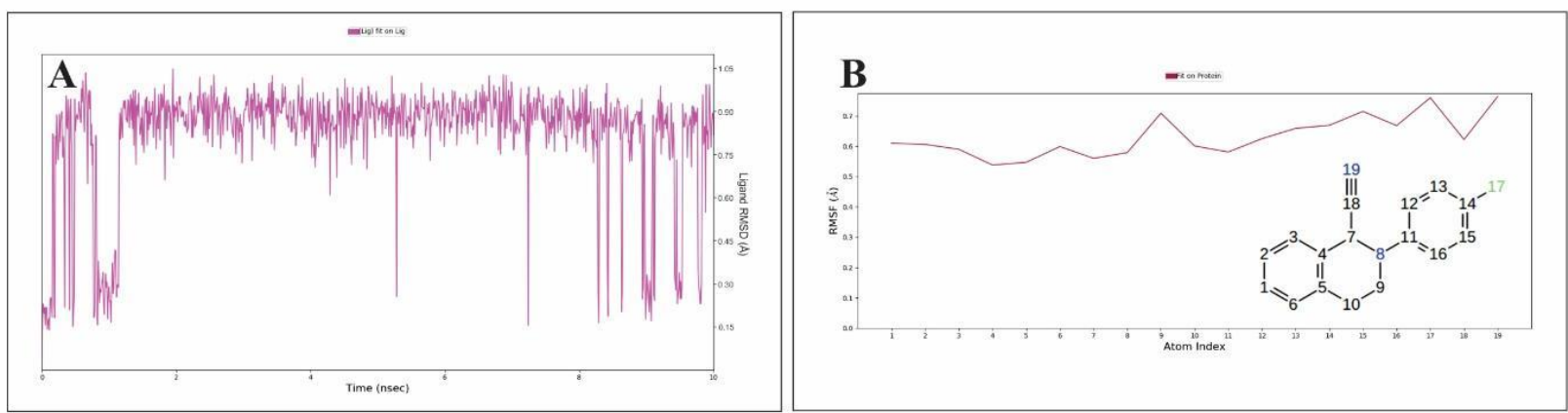

Figure 4. RMSD (A) and RMSF (B) plot of compound 16, obtained during the course of 10 ns molecular dynamics simulation

\section{Conclusion}

A series of 24 1,2,3,4-tetrahydroisoquinoline derivatives were screened for potential XO inhibitory properties. Among them, only compound $16\left(\mathrm{IC}_{50}=\right.$ $135.72 \pm 2.71 \mu \mathrm{M}$ ) exhibited $\mathrm{IC}_{50}$ value below 150 $\mu \mathrm{M}$, and was further subjected to molecular docking and molecular dynamic simulation. Molecular modeling suggests that interactions with Met 1038, Gln 1040, Thr 1077, Gln 1194 and Val 1259 are an important factor for inhibitor affinity toward the XO enzyme. Observed interactions with non-catalytic residues, might be beneficial for the discovery of new active 1,2,3,4-tetrahydroisoquinoline-based inhibitors of XO enzyme.

\section{Acknowledgements}

The financial support of this work by the Ministry of Education, Science and Technological Development of the Republic of Serbia (Grant numbers 451-03-68/2020-14/200113 and 451-03$68 / 2020-14 / 200026$ ) and the Faculty of Medicine of the University of Niš (Internal project No. 40) are gratefully acknowledged. The authors would like to thank D. E. Shaw Research, for providing us the Desmond software package free of cost for this study. 


\section{References}

1. Pacher PA, Nivorozhkin A, Szabó C. Therapeutic effects of xanthine oxidase inhibitors: renaissance half a century after the discovery of allopurinol. Pharmacol Rev 2006;58(1):87-114. [CrossRef][PubMed]

2. Berry $\mathrm{CE}$, Hare JM. Xanthine oxidoreductase and cardiovascular disease: molecular mechanisms and pathophysiological implications. J Physiol 2004;555 (3):589-606. [CrossRef] [PubMed]

3. Ojha R, Singh J, Ojha A, Singh H, Sharma S, Nepali K. An updated patent review: xanthine oxidase inhibitors for the treatment of hyperuricemia and gout (20112015). Expert Opin Ther Pat 2017;27(3):311-45. [CrossRef][PubMed]

4. Šmelcerović $A$, Tomović $K$, Šmelcerović Ž, Petronijević $\check{Z}$, Kocić G, Tomašič $T$, et al. Xanthine oxidase inhibitors beyond allopurinol and febuxostat; an overview and selection of potential leads based on in silico calculated physico-chemical properties, predicted pharmacokinetics and toxicity. Eur J Med Chem 2017;135:491-516. [CrossRef][PubMed]

5. Džambaski Z, Bondžić BP. Dehydrogenative $\mathrm{C}\left(\mathrm{sp}^{3}\right)-\mathrm{H}$ bond functionalization of tetrahydroisoquinolines mediated by organic oxidants under mild conditions. Org Biomol Chem 2019;17(26):6420-5.

[CrossRef][PubMed]

6. Šmelcerovic Ž, Veljković A, Kocić G, Yancheva D, Petronijević $\breve{Z}$, Anderluh $M$, Šmelcerović $A$. Xanthine oxidase inhibitory properties and anti-inflammatory activity of 2-amino-5-alkylidene-thiazol-4-ones. Chem Biol Interact 2015;229:73-81. [CrossRef][PubMed]

7. Tomović $K$, Ilić BS, Šmelcerović Ž, Miljković $M$, Yancheva D, Kojić M, Mavrova AT, Kocić G, Šmelcerović A. Benzimidazole-based dual dipeptidyl peptidase-4 and xanthine oxidase inhibitors. Chem Biol Interact 2020;315:108873. [CrossRef][PubMed]

8. MOE, Molecular Operating Environment (computer program). Version 2019.0101. Montreal (Canada): Chemical Computing Group ULC; 2019.
9. Soga S, Shirai $H$, Kobori M, Hirayama N. Use of amino acid composition to predict ligand-binding sites. J Chem Inf Model 2007;47(2):400-6. [CrossRef][PubMed]

10. Desmond, Desmond Molecular Dynamics System (computer program). Version 2018.4. New York (NY): D.E. Shaw Research; 2018.

11. Okamoto K, Matsumoto K, Hille R, Eger BT, Pai EF, Nishino $\mathrm{T}$. The crystal structure of xanthine oxidoreductase during catalysis: implications for reaction mechanism and enzyme inhibition. Proc Natl Acad Sci U S A 2004;101(21):7931-6. [CrossRef][PubMed]

12. Pauff JM, Cao H, Hille R. Substrate orientation and catalysis at the molybdenum site in xanthine oxidase crystal structures in complex with xanthine and lumazine. J Biol Chem 2009;284(13):8760-7. [CrossRef][PubMed]

13. Li P, Tian Y, Zhai H, Deng F, Xie M, Zhang X. Study on the activity of non-purine xanthine oxidase inhibitor by 3D-QSAR modeling and molecular docking. J Mol Struct 2013;1051:56-65. [CrossRef]

14. Wan $Y$, Zou B, Zeng $H$, Zhang $L$, Chen $M$, Fu G. Inhibitory effect of verbascoside on xanthine oxidase activity. Int J Biol Macromol 2016;93:609-14. [CrossRef][PubMed]

15. Malik N, Dhiman P, Khatkar A. Mechanistic approach towards interaction of newly synthesized hesperidin derivatives against xanthine oxidase. Int J Biol Macromol 2019;135:864-76. [CrossRef][PubMed]

16. Cao W, Fang $Y$, Wu T, Liang $F$, Cheng $Y$, Salah $M$, et al. Insights from multispectral and molecular docking investigation on the xanthine oxidase inhibition by 1,4-dicaffeoylquinic acid. J Mol Struct 2020:128475. [CrossRef]

17. Liu K, Kokubo H. Exploring the stability of ligand binding modes to proteins by molecular dynamics simulations: a cross-docking study. J Chem Inf Model 2017;57(10):2514-22. [CrossRef][PubMed] 


\title{
Originalni rad
}

UDC: $577.152 .1: 547.833$

doi: 10.5633/amm.2021.0106

\section{INHIBICIJA KSANTIN OKSIDAZE DERIVATIMA 1,2,3,4-TETRAHIDROIZOHINOLINA}

\author{
Mihajlo Gajić1, Budimir S. Ilić2, Bojan P. Bondžić3, Zdravko Džambaskiª, Ana Filipović3, \\ Gordana Kocić4, Andrija Šmelcerovićz
}

\begin{abstract}
${ }^{1}$ Univerzitet u Nišu, Medicinski fakultet, Katedra za farmaciju, Niš, Srbija
${ }^{2}$ Univerzitet u Nišu, Medicinski fakultet, Katedra za hemiju, Niš, Srbija

${ }^{3}$ Univerzitet u Beogradu, Institut za hemiju, tehnologiju i metalurgiju, Beograd, Srbija

${ }^{4}$ Univerzitet u Nišu, Medicinski fakultet, Katedra za biohemiju, Niš, Srbija
\end{abstract}

Kontakt: Andrija Šmelcerović

Bulevar dr Zorana Đinđića 48, 18000 Niš, Srbija

E-mail: andrija.smelcerovic@medfak.ni.ac.rs

a.smelcerovic@yahoo.com

Ksantin oksidaza (XO) je metaloflavoproteinski enzim, koji je najpoznatiji po svojoj ulozi ograničavanja brzine razgradnje purinskih nukleotida. Terapijska inhibicija XO zasniva se na njenoj ulozi u brojnim bolestima, koje su povezane bilo sa hiperprodukcijom mokraćne kiseline ili hiperprodukcijom reaktivnih kiseoničnih vrsta. $U$ ovom radu izvršeno je ispitivanje sposobnosti inhibicije XO 24 derivata 1,2,3,4-tetrahidroizohinolina, od kojih je jedinjenje 16 pokazalo $\mathrm{IC}_{50}$ vrednost od $135,72 \mu \mathrm{M} \pm 2,71 \mu \mathrm{M}$. Interakcija jedinjenja 16 sa XO enzimom simulirana je korišćenjem Site Finder modula molekularnog dokinga i molekularne dinamike. Molekulsko modelovanje ukazuje na to da su interakcije sa Met 1038, Gln 1040, Thr 1077, Gln 1194 i Val 1259 važan faktor postojanja afiniteta inhibitora prema XO enzimu. Naš predloženi model vezivanja mogao bi biti od značaja za razvoj novih aktivnih inhibitora XO zasnovanih na 1,2,3,4-tetrahidroizohinolinskom heterociklusu.

Acta Medica Medianae 2021;60(1):48-55.

Ključne reči: inhibicija ksantin oksidaze, 1,2,3,4-tetrahidroizohinolini, molekularni doking, simulacija molekularne dinamike 